Agro-Science Journal of Tropical Agriculture, Food, Environment and Extension Volume 8 Number 2 Mav 2009 pp $97-103$

ISSN 1119-7455

\title{
ASSESSMENT OF TRAINING NEEDS OF EXTENSION STAFF OF AGRICULTURAL DEVELOPMENT PROGRAMME (ADP), EDO STATE, NIGERIA.
}

\author{
Omoregbee, F.E. and Ajayi, M.T. \\ Department of Agricultural Economics \& Extension Services, Faculty of Agriculture, University \\ of Benin, PMB 1154, Benin-city, Edo State, Nigeria.
}

\begin{abstract}
The study assessed the training needs of extension agents in Edo State Agricultural Development Programme (ESADP). The study specifically examined the socio-economic characteristics of the respondents, tasks and new tasks performed by them and the task areas in which they needed further training. Using structured questionnaire, data were collected from seventy six (76) randomly selected extension agents in 3 agricultural zones of Edo State. Findings revealed that the mean age of the respondents was 41.7 years. More than half (55.3\%) of them holders of National Diploma (ND) and about seventy two percent of the respondents had been working in extension service for 6 and 7 years. The tasks performed by the extension staff ranged from advising farmers on improving methods of farming to new task on health issues such as campaign on HIV/AIDS. The study identified strong training needs for Edo State extension agents on communication skills $(\overrightarrow{X=4.60)})$, planning demonstration $(\bar{X}=4.60)$, evaluation of trials $(\bar{X}=4.57)$ and farmers training $(\bar{X}=4.56)$. The correlation analysis showed that education had significant relationship many areas of the respondents' training needs: farmer identification ( $r=-0.190, p \leq 0.05)$, nutrition and food utilization $(r=0.339, p \leq 0.05)$, communication skills $(r=0.190, p \leq 0.05)$, planning demonstration $(r=0.190, p \leq 0.05)$, recording and reporting $(r=0.260, p \leq 0.05)$, evaluation of trials $(r=0.190, p \leq 0.05)$, and rodents and pest control $(r$ $=0.236, p \leq 0.05$ ). Similarly, job experience had significant relationship with the respondents' training need in the area of planning demonstration $(r=0.190, p \leq 0.05)$. It was suggested that there is a need for regular training needs analysis, especially for new recruited agricultural graduates to determine their areas of deficiencies.
\end{abstract}

Key Words: Assessment, Tasks Performed, Training Needs, Extension Staff, ADP.

\section{INTRODUCTION}

The agricultural development programme (ADP) system in Nigeria was institutionalized in 1974 with funding assistance from the World Bank, Federal and State Governments. Edo State ADP was one of the ADPs established in 1985 as Bendel State ADP o However, in 1991 Bendel ADP was bifurcated into Edo and Delta ADPs upon the state creation exercise of August, 1991. The services of Edo State ADP have been in the areas of agriculture, natural resource and human development.

Extension, as an educational input, can make an important contribution to sustainable agricultural production and rural development.
One of the strategies adopted by Edo State ADP in achieving its set objectives was the dissemination of improved agricultural technologies to the farmers, coupled with education about the technologies. Crowder (1996) reported that there is a critical need for a large number of well trained extension workers in many developing countries. The data collected in a study conducted by FAO Global Consultation on Agricultural Extension (1990) revealed that in the USA, Canada and Europe one extension agent covers about 400 economically active persons in agriculture, even before counting the services provided by the private sector. Higher figure was obtained in four developing regions of Africa, Asia, Latin 
America and the Near East where an extension worker covers on average about 2,500 active persons in agriculture.

Today, educational programmes delivered by extension agents in Edo ADP are more varied than ever and will continue to change to meet the needs of the clientele they serve. Radhakvishna and Thomson (1996) further stated that extension agents particularly require experiential learning that provides them with opportunities to relate to rural people in an interactive process that combines scientific technical knowledge with local indigenous knowledge in client-centered problem solving activities.

To satisfy this requirement, there is a need to regularly analyze the technical competence and job performance of extension staff in the organization. Yondeowei and Kwarteng (2006) defined training need as the difference between the required level of individual competence and his present level of competence. Allo (2001) pointed out that one of the main factors limiting the development of effective training programmes for agricultural professionals in developing countries is the inadequacy of information on their training needs. In this regard, there is also the need to rationalize training to minimize repetition of the same message, more exposure to relevant technology and communication techniques, more avenues for personal career development and frequent contact between various categories of extension personnel.

This study is therefore undertaken to assess the training needs of extension staff in Edo State ADP. Specifically, the study aimed to:

- examine the socio-economic characteristics of extension staff of the Edo State ADP;

- $\quad$ identify the new tasks being performed by extension staff of the Edo State ADP;

- $\quad$ determine the task areas in which extension agents needed further training.

Hypothesis of the study

$\mathrm{H}_{0} \quad$ There is no significant relationship between the Edo State ADP Extension workers' socio-economic characteristics and their training needs

\section{RESEARCH METHODOLOGY}

This study was conducted in Edo State Agricultural Development programme (ESADP), Nigeria. Edo State covers a total area of about
17,802 square kilometers with 180,000 farm families. For effective extension coverage, ESADP is divided into three agricultural zones as follows: Edo Central, Edo North and Edo South zone. The Edo central is divided into five blocks as follows: Esan Central, Esan West, Esan North-East, Esan South-East and Igueben Local Government Areas (LGAs). The Edo North Comprises 6 blocks, namely: Owan West, Akoko-Edo, Etsako West, Etsako East, Owan East and Etsako Central LGAs. The Edo South consists of seven (7) blocks namely, Oredo, Ovia south West, Ovia North East, Ikpoba-Okha, Egor, Uhunmwode and Orhionwon LGAs. In all, there are total of 18 blocks or LGAs in the study area. At the time this study was being conducted, there were 80 extension staff in ESADP which was distributed as follows: Edo Central (13), Edo North (28) and Edo South (39). Due to the few numbers of extension staff in Edo State, a proportional sample of $95 \%$ from each zone was randomly selected to have a total of 76 respondents for the study. For the purpose of this study a structured questionnaire was the instrument used for data collection. The training needs of extension staff as conceived in this study implies the assessment of the skills, knowledge and attitudes that are desirable for the extension staff as well as determining how much the present condition departs from those conditions which are optimal for meeting these needs.

Measurement of Variables. Training Needs: The process of analysis of training needs of an organization as stated by Mc Gee and Paul (1961) comprised a three fold approach, namely: organizational, job or occupational and man analysis. This study adopted the job or occupational analysis. It entails identifying tasks performed by the organizational staff and identifying the tasks in which staff require for further re-training to perform them well. Seventeen (17) of such tasks were identified in this study and the respondents were asked to indicate the tasks they perform in which they require re-training. Demographic profile of respondents: A selected personal characteristics of respondents namely age; gender, educational status and job experience were measured. Age was measured in years, gender as male or female, educational status as the highest certificate obtained and job experience as the number of years spent on the job.

Data were analysed using descriptive statistics such as frequency counts, percentages, means and standard deviation. Correlation 
analysis was used to test the hypothesis of the study. Some of the variables were measured using a Likert-type-scale. For example, a 5- point likert- scale ranging from "strongly agree" (5). " agree" (4), "Undecided" (3), "disagree" (2), to "strongly disagree" (1) was used to assess respondents perception of the extension agents training needs. A mean score of 3.50 and above indicates areas of training needs while a mean score lower than 3.50 indicates areas where training are not needed.

\section{RESULTS AND DISCUSSION \\ Personal characteristics of respondents:}

The personal characteristics of the respondents are presented in Table1. More than half $(59.2 \%)$ of the respondents were in the age group of between 40 and 49 years and the remaining $43.8 \%$ of them belonged to different age groups of 20-29 years (4.0\%), 30-39 years $(26.3 \%)$ and 50 years and above $(10.5 \%)$ respectively. This implies that most $(89.5 \%)$ of the extension staff in Edo State ADP is still young. This means that skills acquired through re-training and training programmes can still be utilized in the organization for at least 16years.

As shown in Table1, 57.9\% of the respondents were males while $42.1 \%$ were females. In the past, extension job was reserved for men only believing that it was only men that were farmers and that men needed to reach them (Airemen, 2005). However presently, accepting the fact that women are also farmers and need to be reached in order to achieve increased productivity has necessitated the employment of female extension workers who are believed to be in a better position to do the job of reaching women.

More than half of the respondents were OND holders $(55.3 \%)$. This was followed by HND $(27.6 \%)$, NCE (15.8\%) graduates and a few B.Sc. degree holders (1.3\%). It is generally assumed in Nigeria that extension job is a lowstatus job fit only for job applicants possessing low academic qualifications (Ejembi et al,.2006). Results of this study do not contradict this view Oladoja (2004) indicated that the process of technology transfer should not focus only on the transfer of innovations but also on the transfer of scientific and managerial skills. Agricultural extension staff needs to be trained and retrained to respond well to their functions of communicating and assisting farmers to make decisions on new technologies.

Most $(72.3 \%)$ of the respondents had working experience as extension staff for between 6 and 7 years. Some of them had put in 4-5 years while very few of them had been in the service for 2-3years. The length of service is probably an indicator of a person's commitment to the chosen career (Ejembi et al.2006). Frequent training and re-training programmes are needed to be put in place by an organization to strengthen this commitment. 
Training Needs of Extension Staff of Edo State ADP.

Table 1: Personal characteristics of respondents $(n=76)$

\begin{tabular}{lcc} 
Socio-economic variables & Frequency & Percentage $(\%)$ \\
\hline Gender & & 57.9 \\
Male & 44 & 42.1 \\
Female & 32 & 4.0 \\
Age & 3 & 26.3 \\
20-29 years & 20 & 59.2 \\
30-39 years & 45 & 10.5 \\
40-49 years & 8 & 15.8 \\
50 years and Above & & 55.3 \\
Educational level & 12 & 27.6 \\
NCE & 42 & 1.3 \\
OND & 21 & 6.6 \\
HND & 1 & 13.2 \\
B.Sc. & & 72.3 \\
Job experience & 5 & 7.9 \\
2-3 years & 10 & \\
4-5 years & 55 & \\
6-7 years & 6 & \\
Above 7 years & &
\end{tabular}

Source: Field survey data, 2007.

Table2: Percentage distribution of the respondents on the basis of the tasks being performed by them $(n=76)$.

\begin{tabular}{lll} 
Task s performed & $(\text { No })^{*}$ & $(\%)^{*}$ \\
Establishment of SPAT & 47 & 58.8 \\
Farm visit & 47 & 58.8 \\
Market survey & 35 & 43.8 \\
Provision of farm inputs & 32 & 40.0 \\
Record keeping & 32 & 40.0 \\
Group formation & 29 & 36.3 \\
Linkage to credit facilities & 24 & 30.0 \\
Formation of co-operative groups & 17 & 21.3 \\
Demonstration of improved technologies & 15 & 18.8 \\
Selection of contact farmers & 12 & 15.0 \\
-Formation of women groups & 9 & 11.3 \\
Assist the subject matter specialist & 7 & 8.8 \\
Rendering of technical advise to farmers & 6 & 7.5 \\
Establishment of school programme & 4 & 5.0 \\
Food utilization demonstration & 4 & 5.0 \\
Agro-chemical skill training & 1 & 1.3 \\
Campaign on HIV/AIDS & 1 & 1.3 \\
\hline
\end{tabular}

- Multiple responses Source: Field survey data, 2007.

\section{Tasks Performed by Respondents:}

Data in Table2 reveal the various tasks performed by the ESADP's extension agents. The major tasks performed by the respondents were the establishment of small plot adoption technique (SPAT) (58.8\%), Farm visit (58.8\%), Market survey (43.8\%), provision of farm inputs $(40 \%)$ and record keeping (40\%). The least performed tasks by the respondents were agrochemical skill training $(1.3 \%)$ and campaign on HIV/AIDS (1.3\%). The various tasks performed by the extension staff in agriculture in Table2 portray the fact that agricultural extension involves a great deal more than simply walking into a farm and telling a farmer about a new technology. Allo (2001) asserted that extension is a highly sophisticated technique which demands a considerable range of skills. For extension staff to acquire this sophisticated technique Allo (2001) suggested that in designing a course for extension workers, the following allocation of time should be implemented. These are motivation-20\% of the total time, extension- $20 \%$ of the total time, technology- $40 \%$ of the total time and practical work-20\% of the total time. The inclusion of campaign on HIV/AIDS to the tasks performed by the extension staff showed that they carry out functions beyond their traditional task of offering pieces of advice, helping farmers analyze problems and identifying opportunities, sharing information, supporting group formation and facilitating collective action. They have also included provision of information on health problems to farmers 
Omoregbee, F.E. and Ajayi, M.T.

\section{Respondents' areas of training needs:}

Entries in Table3 indicate that the respondents needed training in the following areas: communication skill $(\bar{X}=4.60)$, planning demonstration ( $\mathrm{X}=4.60)$, Evaluation of trials $\overline{\mathrm{X}}$ =4.57), farmers $(\mathrm{X}=4.52)$, rodents and pest control $\overline{(X}=4.48)$, recording and reporting $\overline{(X}=4.46)$, establishment of SPAT $(\bar{X}=4.46)$, formation of women groups $(\overline{\mathrm{X}}-4.35)$, nutrition and food utilization demonstration $(\bar{X}=4.24)$ and farmer identification $(\bar{X}=4.18)$. These findings indicate that the areas in which respondents expressed training needs are very relevant to knowledge and skills required for executing extension programmes as well as responding to farmers' needs. This is in line with the view of Androulitakis and Siardos (2005) that extension agents' competence should be in accordance with the task areas in which they will be assigned to operate in order to perform successfully. Hence, the importance of in-service training.

The deficiency in extension methodology observed in Table 3 could be as a result of inadequate pre-service training of the respondents. According to Van Crowder (1996), extension methodology is often by-passed in many intermediate levels whose primary function is to train students to work as field extension agents in an effort to insert specialized technical agriculture in the curriculum.

Table 3: Respondents' perception of areas of training needs $(n=76)$.

\begin{tabular}{lll} 
Areas of training needs & Mean & Standard deviation \\
\hline Communication skill & 4.60 & 0.49 \\
Planning demonstration & 4.60 & 0.49 \\
Evaluation of trials & 4.57 & 0.50 \\
Farmers training & 4.56 & 0.50 \\
Selection of contact farmers & 4.52 & 0.75 \\
Rodents and pest control & 4.48 & 0.50 \\
Recording and reporting & 4.46 & 0.75 \\
Establishment of SPAT & 4.46 & 0.84 \\
Formation of women groups & 4.35 & 0.48 \\
Nutrition and food utilization demonstration & 4.24 & 0.43 \\
Farmer identification & 4.18 & 0.92 \\
\hline
\end{tabular}

Likert scale: 5 = strongly agree, 4 = Agree, 3 = Undecided, 2 = Disagree, 1 = Strongly disagree.Training is needed whenX $>3.50$ Source: Field survey data, 2007

Table 4: Relationship between some selected respondents' personal characteristics and their training needs.

\begin{tabular}{llll} 
Training needs & Age & Education & Job experience \\
\hline Farmer identification & -0.16 & $-0.190^{*}$ & 0.034 \\
Selection of contact farmers & 0.111 & -0.011 & 0.025 \\
Nutritional and food utilization & -0.148 & $0.339^{*}$ & 0.053 \\
Demonstration & & & \\
Establishment of SPAT & 0.019 & 0.110 & 0.018 \\
Communication skills & 0.139 & $0.190^{*}$ & 0.074 \\
Farmers training & 0.046 & 0.035 & 0.090 \\
Formation of women groups & 0.050 & 0.066 & 0.080 \\
Planning demonstration & -0.107 & $0.190^{*}$ & $0.190^{*}$ \\
Recording and reporting & -0.139 & $0.260^{*}$ & 0.040 \\
Evaluation of trials & 0.031 & $0.190^{*}$ & 0.123 \\
Rodents and pest control & -0.117 & $0.236^{*}$ & -0.090 \\
\hline
\end{tabular}

- $\quad$ Significant at $\mathrm{p} \leq \mathbf{0 . 0 5}$

Source: Field survey data, 2007. 


\section{Relationship between respondents' personal characteristics and their training needs:}

Table 4 shows the relationship between respondents' personal characteristics and their training needs. The table shows that education had significant relationship with many areas of respondents' training needs: : farmer identification $(\mathrm{r}=-0.190, \mathrm{p} \leq 0.05)$, nutrition and food utilization $(\mathrm{r}=0.339, \mathrm{p} \leq$ $0.05)$, communication skills $(\mathrm{r}=0.190, \mathrm{p} \leq$ $0.05)$, planning demonstration $(\mathrm{r}=0.190, \mathrm{p} \leq$ $0.05)$, recording and reporting $(\mathrm{r}=0.260, \mathrm{p} \leq$ $0.05)$, evaluation of trials $(r=0.190, p \leq 0.05)$, and rodents and pest control $(\mathrm{r}=0.236, \mathrm{p} \leq$ 0.05 ). This result is not unexpected because technical skills are easily acquired through education. Similarly, job experience had significant relationship with the respondents' training need in the area of planning demonstration $(\mathrm{r}=0.190, \mathrm{p} \leq 0.05)$. However, age of respondents was not significantly related to the training needs of respondents. It is possible that age may not be a significant factor in determining training needs. Old or young people can be re-trained to enhance their competence on the job.

\section{CONCLUSION AND RECOMMENDATIONS}

This study established that there were more males' extension agents in ESADP than females. The study also established that majority of the ESADP's extension agents were either OND or HND holders with majority having 6-7 years of working experience. The study also established that ESADP's extension agents performed other task other than their traditional tasks. It was also established that many extension agents were deficient in the important subject matter areas that are necessary for extension agents to perform effectively such as communication skills, planning demonstration, evaluation of trials, farmers training and selection of contact farmers. The implication of these findings is that most of these subject areas are likely to be lacking in the pre-service training curriculum of the agricultural graduates recruited as extension agents in ADPs.

Based on the findings and conclusion reached in this study the following recommendations were made:

Training needs analysis should be carried out for new recruit graduates and also periodically to determine the training needs of extension agents.

- $\quad$ In-service training should be planned for extension agents in social science skills that are mostly deficient in agricultural graduates such as communication skills, evaluation and research methods.

There is a need for collaboration between ADPs and agricultural institutions in reviewing agricultural extension curriculum in agricultural institutions that will assist the agricultural extension graduates in facing new challenges so as to perform effectively and efficiently as extension agents.

\section{REFERENCES.}

Airemen, S.A. (2005). Training needs of extension staff in agriculture: A case study of EdoState agricultural development programme. Unpublished B.Sc thesis. Department of agricultural economics and extension, Faculty of Agriculture, University of Benin, Benin-City. pp 10-18.

Allo, A.V. (2001). Professional requirements of the extension worker in training the extension worker. FFTC extension bulletin No. 173 .

Androuhdkis, S.I. and G.C. Siardos (2005).Agricultural extension agents' perception regarding their relevance and competence in certain professional task areas. Jimmyproject materials II. 4p. Available at www.jimmy project.org.

Crowder, L.V. (1996). Assessment of preservice and in-service extension education. Agricultural extension and education service (SDRE). FAO Research, extension and training division. 3p. Also availabl atwww.fao.org/sd/exdirect/exan 001.htm.

Ejembi, E.P; F.E.Omoregbee and S.A.Ejembi (2006). "Farmers' assessment of the training and visit extension system in central Nigeria: Evidence from Barkin Ladi,Plateau State". Journal of Social Sciences. 12 (3):207-212.

Food and Agriculture Organization (FAO) (1990). Global consultation on agricultural extension.

McGee, W and T. Paul (1961). Training in business and industry. Wiley publishers. New York. USA. pp 3036.

Oladoja, A.M. (2004).Analysis of the training needs of extension agents in Lagos State ADP.Unpublished B.Sc. Thesis. Department of Agricultural Extension and RuralDevelopment. Faculty of Agriculture, University of Ibadan.pp 50-53. 
Radhakrishna, R.B and J.S. Thomson (1996).'Extension agents' use of information sources. Journal of Extension. 34(1):12-17.
Youdeowei,A and Kwarteng, J. (2006). Tool Kit for the production of agricultural extension materials. Guide book. CTA Wageningen, The Netherlands.50pp. 